\title{
Facial Nerve Palsy after General Anaesthesia, A Less Reported Complication: Case Report
}

\author{
Rajesh Chaudhary ${ }^{*}$, Kulbhushan Sharma ${ }^{2}$, Ankit Shukla ${ }^{3}$, Atul Gupta ${ }^{4}$, Manju bansal ${ }^{5}$ and Aakash Parashar \\ ${ }^{1,3}$ Department of Surgery, Senior Resident, Dr. R.P. Govt. Medical College Kangra, India \\ ${ }^{2}$ Department of Surgery, Zonal Hospital Dharamshala HP, India \\ ${ }^{4}$ Department of Paediatrics, Zonal Hospital Dharamshala HP, India \\ ${ }^{5}$ Department of Medicine, Zonal Hospital Dharamshala HP, India \\ ${ }^{6}$ Department of Orthopaedics, Zonal Hospital Dharamshala HP, India
}

Submission: November 9, 2016; Published: November 30, 2016

*Corresponding author: Rajesh Chaudhary, Senior Resident, Department of Surgery, Dr. Rajendra Prasad Government Medical College, Kangra,

Tanda HP, India, Email: topgun.chaudhary@gmail.com

\section{Abstract}

Peri-operative nerve injuries are less documented but known complications. They are more common after regional anaesthesia but may be seen after general anaesthesia too. Peripheral branches of facial nerve are likely to be injured due to pressure exerted during bag and mask ventilation or due to stretch exerted while pulling the jaw forward. Most of the times these injuries are transient and recover within the time period of few days to weeks without any residual effects or they could be serious and permanent. Difficult intubation may invite trouble and cause facial nerve injury.

Keywords: Facial nerve palsy; Neuroprexia; Peripheral nerve injuries; Regional anaesthesia

\section{Introduction}

Injury to the peripheral nerves in the peri-operative period is a rare but sometimes serious, documented complication. These injuries are a source of great anxiety and morbidity to the patients and their families besides they are leading cause of insurance claims. According to one data these injuries are a cause of litigation against anaesthetists as high as $16 \%$. [1] These injuries may be minor and transient or permanent. Although there exact incidence is not known but one study has put the permanent nerve damage after surgery and anaesthesia to be somewhere between $0.03 \%$ $1.4 \%$. Facial nerve injury may be seen after general anaesthesia which usually improves with the passage of time leaving the permanent damage only in a minor number of patients. The nerve is vulnerable to trauma due to variability in its course or sometimes because of its superficial nature, which makes it vulnerable to pressure and stretch [2]. Use of inappropriate size laryngeal mask airway(LMA) or endotracheal tube or a difficult intubation increase the chances of injury as highlighted by this case .

\section{Case}

We present the case of a 48 year old male weighing $65 \mathrm{~kg}$ who was posted for elective cholecystectomy. There was no history of any co morbidities but a difficult intubation was anticipated by the anaesthetist in view of short neck and a large tongue. At the operating table the induction of anaesthesia was started by the anaesthetist with $2(\mathrm{mg})$ miligram $/ \mathrm{kg}$ of Propofol along with 2 microgram $/ \mathrm{kg}$ of Fentanyl and $0.5 \mathrm{mg} / \mathrm{kg}$ of Succinylcholine was given intravenously after preoxygenation with $100 \%$ oxygen for three minutes with bag and mask. An Endotracheal tube of size 7.5 was used but the trachea could not be intubated.

A size 6.5 tube also could not be negotiated into the trachea of the patient. Meanwhile the patient was again ventilated with $100 \%$ oxygen and laryngeal mask airway of size 4 was tried after proper lubrication with lignocaine jelly by another anaesthetist but the procedure again failed even after two attempts. The procedure was abandoned and patient shifted back towards after recovery. About six hours later the patient was seen in the 
wards. Patient complained of perioral numbness and difficulty in speaking. Angle of mouth was deviated towards left side. No other neurological sign was seen.

Anticipating some cerebrovascular accident plain CT scan of the head was done and it was found to be normal. The case was discussed with the physician also but no obvious cause could be found. We had never seen such a condition before hence extensive search of literature available over internet was made. A transient injury of the facial nerve was kept as the diagnosis. Prognosis was explained to the patient and counselling done regarding future outcome of the condition. Within a week the patient made full recovery and is still in follow up.

\section{Discussion}

The perioperative peripheral nerve injuries are more common after regional anaesthesia techniques but are seen after general anaesthesia too. Different nerves injured in decreasing order of frequency are ulnar nerve, brachial plexus, lumbosacral root, spinal cord, sciatic nerve, median nerve, radial nerve and femoral nerve respectively. Facial nerve injury is further rare [3]. Peripheral facial nerve injury is a mononeuropathy which is more commonly idiopathic or primary as compared to secondary to known causes like trauma, tumors, ischemia, viral infections or local anaesthetic agent toxicity [4]. Facial nerve is primarily a motor nerve with small sensory component. Facial nerve emerges out of the skull through stylomastoid foramen and becomes superficial to the mandible by entering the parotid gland where it gives off temporal, zygomatic, buccal, marginal mandibular and cervical branches. The main trunk may give off branches at different level in relation to the parotid gland. Digital pressure behind the mandible or excessive pressure exerted by the facemask can cause a traumatic lesion of the facial nerve. Sometimes the branches of facial nerve may be superficial to the parotid gland making the buccal and marginal mandibular branches especially vulnerable to injury during bag and mask ventilation for general anaesthesia [5].

On the basis of nerve pathology, Seddon [6] classified the nerve injuries into three categories. Neurapraxia is the simplest of injuries with damage only to the myelin sheath and an intact axon. The chances of recovery are excellent. When the axon is damaged but the endoneurium and supporting connective tissue framework is preserved, it is called Axonotmesis. The chances of recovery are variable. Neurotmesis is the most severe injury where the nerve is completely destroyed along with the connective tissue network and the chances of recovery are almost negligible [6].

Facial nerve injury could be because of unknown (Idiopathic) or known (Secondary) causes. Idiopathic facial nerve injury is more common [4]. Various mechanisms of nerve injury are ischemia, direct trauma, stretch and compression, and drug toxicity. Patients having diabetes mellitus, smokers, poor general health, pre-existing neuropathies are more prone to nerve injuries. These injuries are more common in neurosurgery, cardiac surgeries, and orthopaedic surgeries and with longer hospital stays. Endotracheal intubation and laryngeal mask airway (LMA) are known to cause nerve injuries.

Trauma while insertion or using a small size tube or LMA should be avoided. Inappropriate cuff size increases the chances of injury by exerting more pressure to occlude the airway [2]. Sometimes the jelly used while insertion of LMA may cause transient nerve paralysis. Onset of symptoms may be immediate in case of direct trauma to the nerve or may be delayed in case of inflammation and drug toxicities. The diagnosis is mainly clinical aided by MRI (Magnetic resonance imaging) and nerve conduction studies. Generally the recovery of peripheral facial nerve injuries is good with a complete recovery in about $85 \%$ over a period of weeks to months while as much as $15 \%$ may suffer a permanent damage leading to weakness, synkinesis, facial spasms, contractures, decreased tears or psychosocial effects [4].

\section{Conclusion}

The peripheral nerve injuries in the perioperative period are a less documented complication .They are a source of great discomfort for the patients and their families as well as a matter of litigation against the doctors. They are very rarely seen after general anaesthesia as compared to regional anaesthesia. Their incidence may be under reported and less but every reported case will add to the better understanding, early and good management of these injuries. They may be very less in context of total perioperative complications but are lifelong for those who suffer permanent damages. One should be aware about the possibility of a nerve injury. Patients should be counselled about the injury and it's possible outcomes and followed up from time to time. A good sense of observation and awareness of a possible nerve injury may prevent such complications.

\section{Consent}

Written informed consent was obtained from the patients for publication of this Case report and any accompanying images. A copy of the written consent is available for review by the Editorin-Chief of this journal.

\section{References}

1. Sawyer RJ, Richmond MN, Hickey JD, Jarrratt JA (2000) Peripheral nerve injuries associated with anaesthesia. Anaesthesia 55: 980-991.

2. Pathak L (2013) Perioperative nerve injury. Health Renaissance 11(3): 260-266.

3. Cheney FW, Domino KB, Caplan RA (1999) Nerve injury associated with anesthesia: a closed claims analysis. Anesthesiology 90(4): 10621069.

4. Finsterer J (2008) Management of peripheral facial nerve palsy. Eur Arch Otorhinolaryngol 265(7): 743-752.

5. Fuller JE, Thomas DV (1956) Facial nerve paralysis after general anesthesia. J Am Med Assoc 162(7): 645.

6. Seddon HJ (1943) Three types of nerve injury. Brain 66: 237-288. 
Your next submission with JuniperPublishers will reach you the below assets

- Quality Editorial service

- Swift Peer Review

- Reprints availability

- E-prints Service

- Manuscript Podcast for convenient understanding

- Global attainment for your research

- Manuscript accessibility in different formats ( Pdf, E-pub, Full Text, Audio)

- Unceasing customer service

Track the below URL for one-step submission http://juniperpublishers.com/online-submission.php 